\title{
DESAIN DAN IMPLEMENTASI INVERTER 3 FASA DENGAN PENAMBAHAN PUSH-PULL CONVERTER
}

\author{
Fifi Hesty Sholihah \\ Departemen Mekanika dan Energi, Program Studi Sistem Pembangkit Energi \\ Politeknik Elektronika Negeri Surabaya \\ Email: fifi@pens.ac.id \\ Nur Rohmat Hadianto \\ Departemen Mekanika dan Energi, Program Studi Sistem Pembangkit Energi \\ Politeknik Elektronika Negeri Surabaya \\ Email:nrohmat614@gmail.ac.id \\ Mustaghfiri \\ Departemen Mekanika dan Energi, Program Studi Sistem Pembangkit Energi \\ Politeknik Elektronika Negeri Surabaya \\ Email: mustaghfiri28@gmail.com
}

\begin{abstract}
ABSTRAK
Energi surya merupakan jenis renewable energy yang mempunyai potensi besar di indonesia. Energi surya dapat dikonversi menjadi energi listrik menggunakan PV. Berhubung dengan meningkatnya kebutuhan energi di Indonesia serta diberlakukan feed in tariff oleh pemerintah, maka akan mempermudah untuk jual beli listrik melalui sistem on-grid. Pada penelitian ini membahas desain dan implementasi inverter 3 fasa yang terkoneksi grid. Rangkaian inverter 3 fasa ini menggunakan sinyal sinusoidal pulse width modulation (SPWM) yang dibangkitkan oleh Arduino. Kemudian sinyal SPWM digunakan untuk masukan rangkaian driver IR2113. Pada perancangan ini menambahkan push-pull converter sebagai suplai inverter 3 fasa. Push-pull converter menggunakan sinyal PWM dari IC SG3525. Duty cycle yang dihasilkan dapat diatur sesuai dengan tegangan yang ingin dihasilkan. Rangkaian ini menggunakan high frequency transformer sebagai step up tegangan. Pada variasi tegangan input 36 volt sampai 66 volt menghasilkan tegangan yang stabil pada 440 volt. Pada pengujian sistem menggunakan tegangan grid 175 volt. Sehingga menghasilkan tegangan line-line 311 Vrms dan tegangan line-neutral 179,5 Vrms.
\end{abstract}

Kata kunci: SPWM; inverter 3 fasa; push-pull converter.

\begin{abstract}
Solar energy is a type of renewable energy that has great potential in Indonesia. Solar energy can be converted into electrical energy using $P V$. Due to the increased demand for electrical energy in Indonesia and the enactment of the Feed-in Tariff by the government, it will make it easier to buy and sell electricity through an on-grid system. This study discusses the design and implementation of the three-phase gridconnected inverter. The circuit of 3-phase inverter uses the sinusoidal pulse width modulation (SPWM) signal generated by the Arduino. Then SPWM signals are used to input the IR2113 driver circuit. In this design add push-pull converter as supply 3 phase inverter. The push-pull converter uses the PWM signal from IC SG3525. Duty cycles can be adjusted according to the voltage you want to generate. This series uses high-frequency transformers as a voltage step up. At a variation of the input voltage, 36 volts to 66 volts produce a stable voltage at 440 volts. At grid testing using grid voltage 175 volts. Thus, the result of the line-line voltage is 311 Vrms and the line-neutral voltage is $179.5 \mathrm{Vrms}$.
\end{abstract}

Keywords: SPWM; 3 phase inverter; push-pull converter.

\section{PENDAHULUAN}

Pada saat ini, renewable energy menjadi topik kajian yang sangat popular di dunia. Energi surya merupakan salah satu dari renewable energy yang jumlahnya sangat melimpah, ramah lingkungan, dan mudah diimplementasikan. Berdasarkan data dari Dewan Energi Nasional potensi energi surya di Indonesia rata-rata sebesar $4.80 \mathrm{kWh} / \mathrm{m} 2 /$ day [1]. Energi surya dapat dimanfaatkan secara langsung untuk memenuhi kebutuhan listrik menggunakan menggunakan modul photovoltaic (PV).

Penelitian mengenai implementasi energi surya berkembang sangat pesat pada saat ini. Salah satu contohnya adalah penggunaan PV untuk memenuhi energi listrik pada bangunan. Pada umumnya, PV membutuhkan beberapa rangkaian elektronika daya seperti DC-DC converter dan inverter. DC-DC boost converter yang dilengkapi control 
PI digunakan untuk menaikan tegangan input hingga mencapai tegangan DC-link, kemudian tegangan DC link diubah menjadi tegangan AC menggunakan inverter [2]. Salah satu teknik penyaklaran pada inverter adalah SPWM yang dibangun dengan membandingkan gelombang sinus dengan sinyal segitiga [3]. Teknik penyaklaran SPWM juga bisa dibangkitkan secara digital menggunakan lookup table pada program mikrokontroller [4].

Pada umumnya, inverter on-grid menggunakan DC-DC converter untuk menaikan tegangan PV agar sesuai tegangan DC link. Diantara beberapa DC-DC converter yang sering digunakan adalah boost converter. Tetapi pada faktanya, tegangan input yang dibutuhkan inverter 3 fasa sangat tinggi. Dan tegangan output boost converter hanya dipengaruhi duty cycle. Jadi boost converter sulit digunakan untuk mencapai tegangan yang dibutuhkan inverter jika tegangan PV berbeda jauh terhadap DC link. Dibawah ini skema inverter menggunakan boost converter [4].

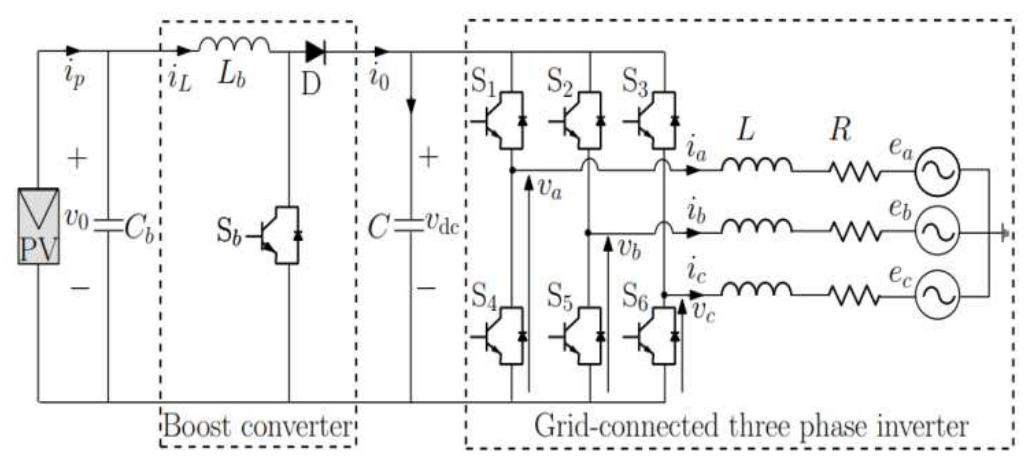

Gambar 1. Penelitian Sebelumnya

Penelitian yang serupa telah dilakukan dengan menggunakan konfigurasi inverter jenis A untuk aplikasi solar power plant berskala besar [5]. Sedangkan untuk solar power plant berskala kecil, inverter 3 fasa lebih disarankan untuk diaplikasikan karena inverter 3 fasa memiliki teknik swtching yang lebih mudah.

Pada penelitian ini kami merancang inverter tiga fasa yang terkoneksi grid pada sistem photovoltaik. Pada sistem ini ditambahkan push-pull converter yang digunakan untuk menaikkan tegangan PV. Tegangan output pushpull converter dikontrol secara close loop. Kelebihan dari sistem ini yaitu dapat menghasilkan tegangan yang besar dengan dimensi yang lebih kecil dan tegangan output dapat dikendalikan sesuai tegangan yang digunakan. Pada sistem koneksi grid menggunakan metode SPWM, karena memiliki rangkaian yang kokoh dan mudah untuk diimplementasikan. Metode ini sangat mudah menyesuaikan, karena pembangunan gelombang mengambil referensi secara langsung melalui grid.

\section{METODOLOGI PENELITIAN}

Pada saat ini, pemakaian PV(photovoltaik) dengan sistem terkoneksi grid lebih populer daripada stand alone. Sistem terkoneksi grid leih hemat biaya karena tidak membutuhkan baterai namun sebagai opsi saja. Penggunaan sistem PV terkoneksi grid memanfaatkan alat yang mampu untuk mengirim atau mengalirkan arus yang dihasilkan PV masuk ke jaringan grid, sehingga daya yang digunakan dalam grid untuk pembebanan akan semakin ringan atau berkurang. Alat tersebut ialah inverter on-grid. Kebanyakan inverter on- grid yang digunakan ialah inverter on-grid 1 fasa. Pada penelitian ini, kami merancang sebuah inverter 3 fasa terkoneksi grid pada sistem PV untuk dapat digunakan bagi bangunan yang memiliki jaringan 3 fasa. Konsep inverter on-grid hamper sama dengan inverter offgrid, namun gelombang sinus yang dihasilkan pada tegangan AC yang dikeluarkan haruslah sama dengan gelombang yang dimiliki oleh grid agar terjadinya sinkronisasi jaringan. Sinkronisasi grid memiliki beberapa variabel yang harus dikondisikan yaitu tegangan, frekuensi, dan fasa pada output inverter harus sama dengan grid yang digunakan. Pada gambar 1 menunjukkan diagram blok dari sistem yang kami rancang.

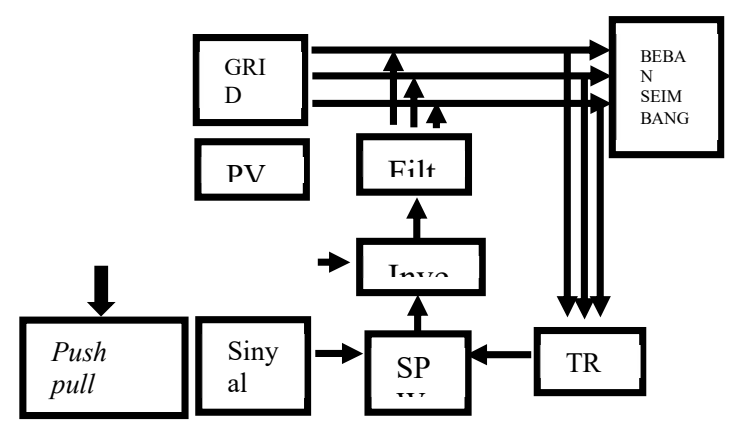

Gambar 2. Diagram Blok Penelitian 
PV module yang digunakan pada penelitian ini memiliki daya maksimum $180 \mathrm{Wp}$, tegangan maksimum 35.4 V, dan arus maksimum 5.09 A. Spesikasi PV yang digunakan diperoleh dari pengujian Standart Test Condition (STC). Desain sistm ini menggunakan dua PV yang disusun secara seri. Dengan mempertimbangkan radiasi sinar matahari dan temperatur yang tidak bisa mencapai kondisi ideal pada pengujian, sehingga tegangan output PV yang digunakan sebagai paramater adalah $60 \mathrm{~V}$.

\subsection{Push-Pull Converter}

DC-DC converter digunakan untuk memberi suplai tegangan yang dibutuhkan oleh inverter 3 fasa. Pada penelitian ini DC - DC converter yang digunakan ialah topologi push pull converter, dimana antara sisi input dengan output terisolasi oleh transformator. Tegangan output push pull converter dapat divariasikan dengan mengatur variasi duty cycle. Push-pull converter pada dasarnya terdiri dari dua saklar (transistor), transformator, dioda penyearah dan filter seperti gambar 2.

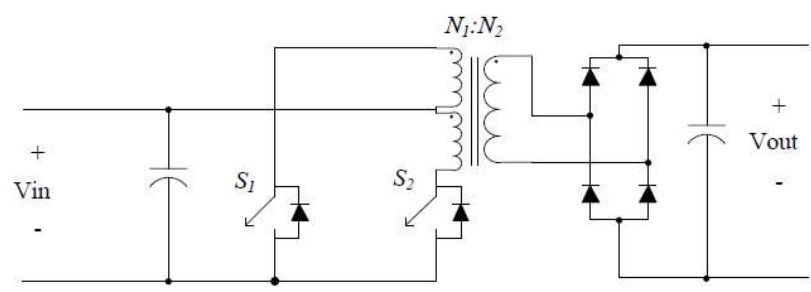

Gambar 3. Push-Pull Converter

Sisi primer transformator disuplai arus dari S1 dan S2 yang dipicu secara bergantian. Sehingga menghasilkan arus bolak balik menuju transformator. Tegangan keluaran pada sekunder transformator disearahkan menggunakan dioda. Pada perancangan kami menggunakan penyearah gelombang penuh dengan empat dioda, sehingga tidak memerlukan center tap (CT) pada sisi sekunder transformator. Filter kapasitor digunakan agar tegangan output push-pull converter menjadi DC murni. Tegangan output inverter yang diharapkan adalah 380 Vrms. Agar mencapai nilai tersebut inverter memerlukan tegangan DC sebesar 538 volt. Jadi, push-pull converter didesain untuk mengonversi $60 \mathrm{~V}$ menjadi $538 \mathrm{~V}$. Persamaaan (1) digunakan untuk menentukan tegangan keluaran push-pull converter.

Vout $=2 \frac{N 2}{N 1} D$. Vin

Untuk menghindari drop tegangan, tegangan output pada desain dibuat lebih besar dari tegangan output yang diharapkan. Berdasarkan perhitungan, rasio lilitan push-pull transformator adalah 7+7 lilitan untuk primer dan 80 lilitan untuk sekunder. Frekuensi switcing yang digunakan untuk push pull konverter adalah $40 \mathrm{KHz}$. Karena kedua transistor harus diaktifkan bergantian, maka duty cycle yang digunakan tidak boleh melebihi 0.5. Modul voltage-mode PWM SG3525 digunakan untuk mengatur duty cycle. Selain itu juga dapat digunakan untuk menjaga tegangan output agar tetap konstan[6]. Tegangan output dikontrol secara close loop dan tegangan yang diinginkan diatur menggunakan resistor pembagi tegangan. Konfigurasi kontrol PWM pada push-pull converter yang dilengkapi feedback seperti gambar dibawah.

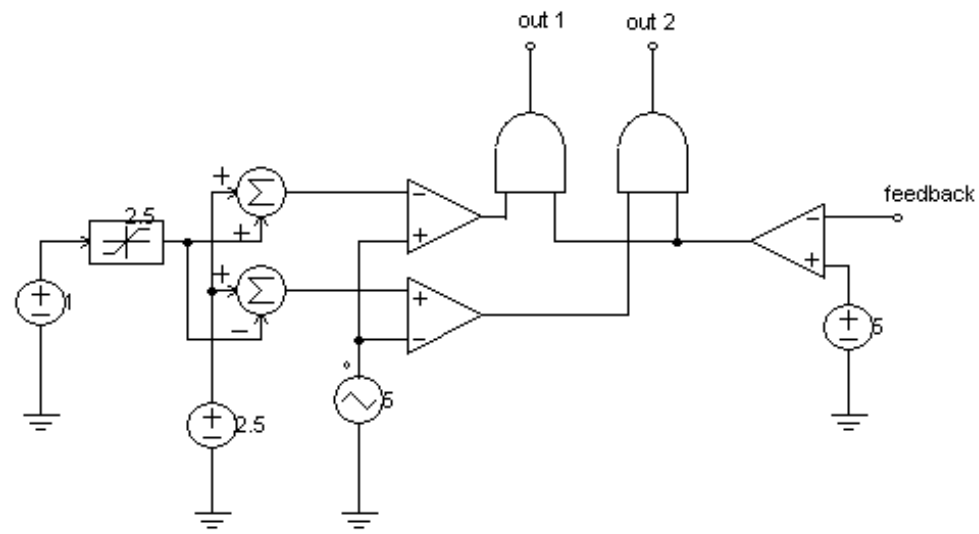

Gambar 4. Kontrol PWM Push-Pull Converter 


\subsection{Inverter 3 fasa}

Inverter merupakan rangkaian yang digunakan untuk mengubah tegangan DC ke AC. Salah satu tipe inverter yang paling umum adalah voltage source inverter (VSI). Inverter tiga fasa banyak digunakan untuk peralatan yang membutuhkan daya tinggi. Rangkaian dasar inverter tiga fasa terdiri dari 6 saklar seperti pada gambar 4. Karakteristik komponen elektronika yang sesuai sebagai saklar harus memiliki rating daya yang tinggi dan dapat digunakan untuk switching pada frekuensi tinggi. Sehingga Insulated Gate Bipolar Transistor (IGBT) dipilih untuk desain inverter tiga fasa.

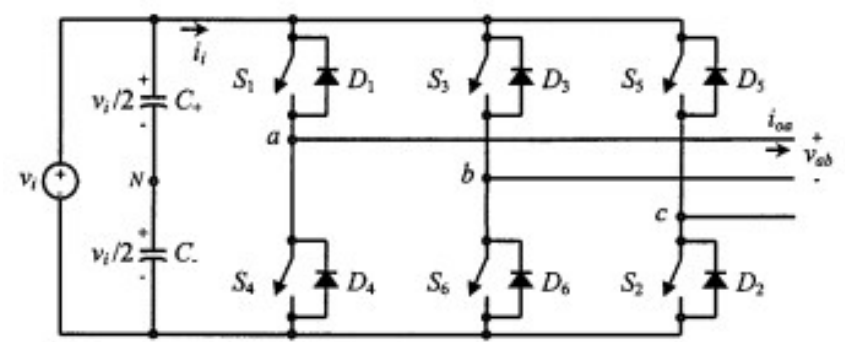

Gambar 5. Inverter 3 Fasa

\subsection{SPWM}

Pada inverter, proses pembentukan gelombang sinus pada output inverter terjadi akibat dari penyaklaran MOSFET/IGBT yang digunakan. Penyaklaran tersebut membentuk sinyal sinusoidal. Metode SPWM merupakan salah satu metode penyaklaran yang sering digunakan untuk menghasilkan output inverter yang membentuk sinyal sinusoidal. Pada penelitian ini metode SPWM juga digunakan sebagai metoda kendali sinkronisasi grid. SPMW dibangun dari perbandingan sinyal sinus(AC) dengan sinyal carrier(segitiga) yang nantinya menghasilkan sinya SPWM. Agar terjadinya sinkronisasi hal pertama yang yang harus diperhatikan ialah sudut fasa dan frekuensi yang dimiliki oleh grid. Sedangkan tegangan akan dikendalikan oleh DC-DC converter. Untuk dapat menghasilkan sinyal sinus yang sama dengan grid,sinyal sinus yang dibandingkan ialah sinyal yang diambil langsung dari grid. Agar sinyal sinus dapat terbaca oleh komponen op-amp, tegangan grid diturunkan hingga 3VAC lalu dibandingkan dengan sinyal carrier yang dibangkitkan sendiri. Berikut bentuk sinyal yang diproses agar mengasilkan sinyal SPWM.

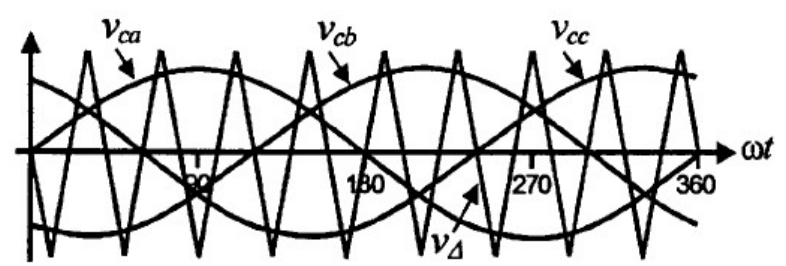

(a)

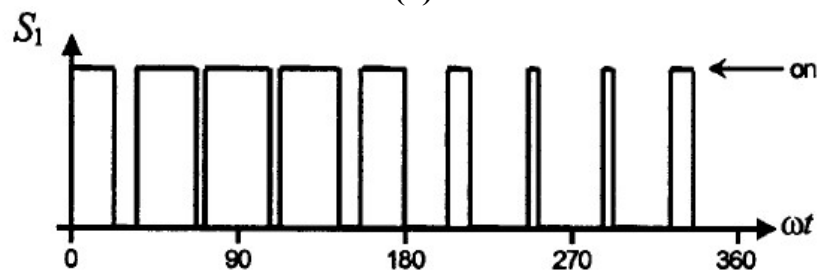

(b)

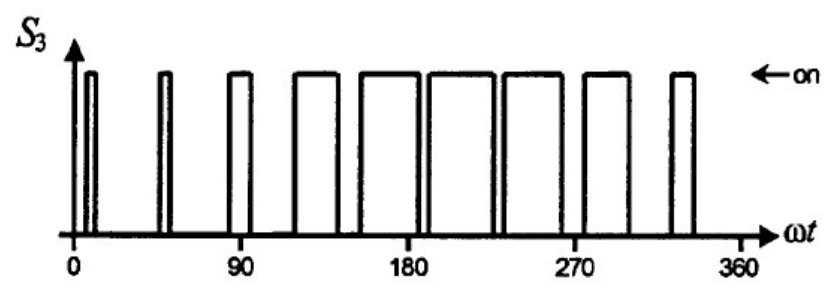

(c) 


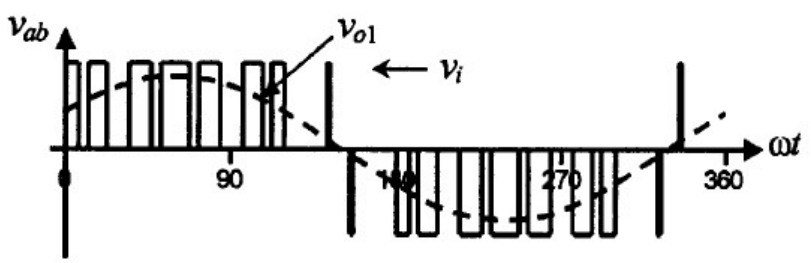

(d)

Gambar 6. a) Sinyal Sinus Dan Segitiga B) Sinyal Gate S1 C) Sinyal Gate S3 D) Output Inverter

Karena sinyal sinus yang dibandingkan berasal dari grid, sinyal output SPWM akan memiliki fasa dan frekuensi yang sama dengan yang dimiliki oleh grid. Dengan begitu kendali sinkronisasi dapat dilakukan menggunakan metode ini.

\subsection{LC filter}

Output inverter pada umumnya memiliki sinyal yang belum smooth berbentuk sinus. Namun berbentuk sinyal multilevel yang berbentuk sinus. Untuk menghasilkan sinyal sinus yang bagus diperlukannya filter pasif yang juga berguna untuk meredam harmonisa. Perancangan filter pasif dirancang berdasarkan harmonisa orde ke-2 dengan persamaan sebagai berikut.

\section{HASIL DAN PEMBAHASAN}

Rangkain dibawah ini merupakan gabungan dari push pull converter, three phase inverter dan kontrol pada masing- masing rangkaian. Simulasi menggunakan dua PV yang dihubungkan seri. Radiasi dan temperatur beturutturut $1000 \mathrm{~W} / \mathrm{m} 2$ dan $25^{\circ} \mathrm{C}$. Hasil simulasi menggunakan software PSIM dapat dilihat pada gambar dibawah ini.

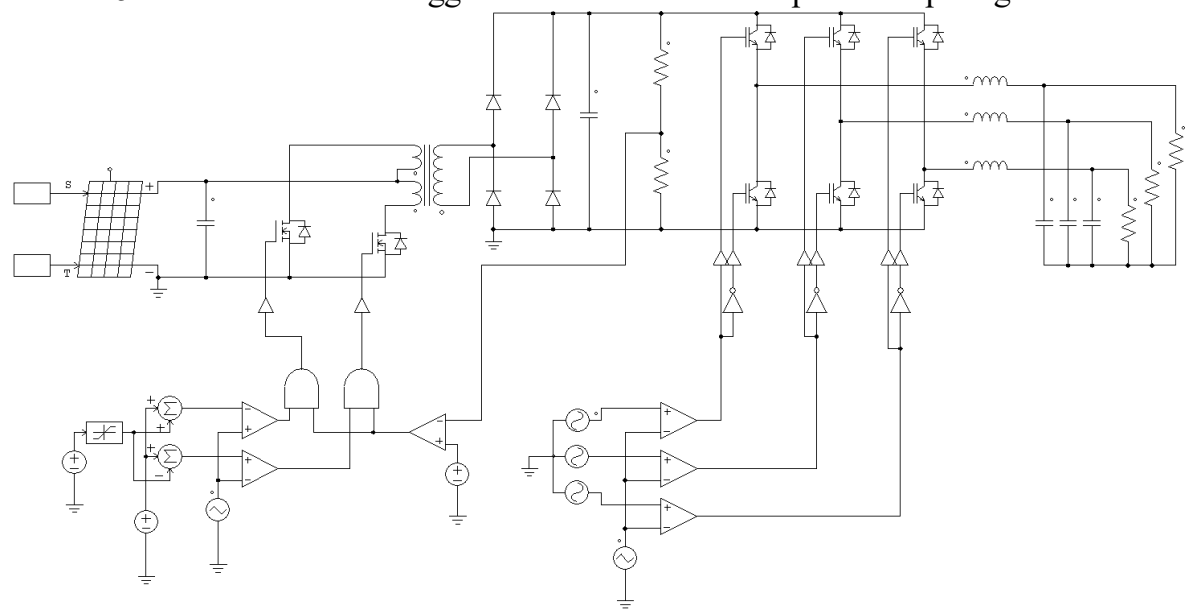

Gambar 7. Skema Rangkaian yang Diusulkan

Pada gambar dibawah ini merupakan gambar sinyal switcing pada gate transistor dan tegangan output pushpull converter. Dengan menggunakan voltage-mode PWM SG3525, maka tegangan output push-pull converter dapat di adjustable sesuai tegangan grid yang digunakan. Selain itu dapat mempertahankan tegangan output yang diakibatkan fluktuasi tegangan input.

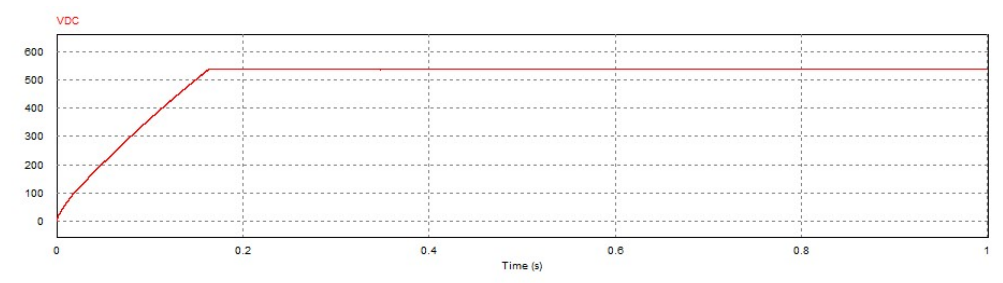

Gambar 8. Tegangan Output Push-Pull Converter 
Inverter 3 fasa menggunakan modulasi SPWM yang didapatkan dari membandingkan sinyal sinus dengan sinyal segitiga. Hasil komparator yang digunakan sebagai input gate inverter seperti gambar dibawah ini.

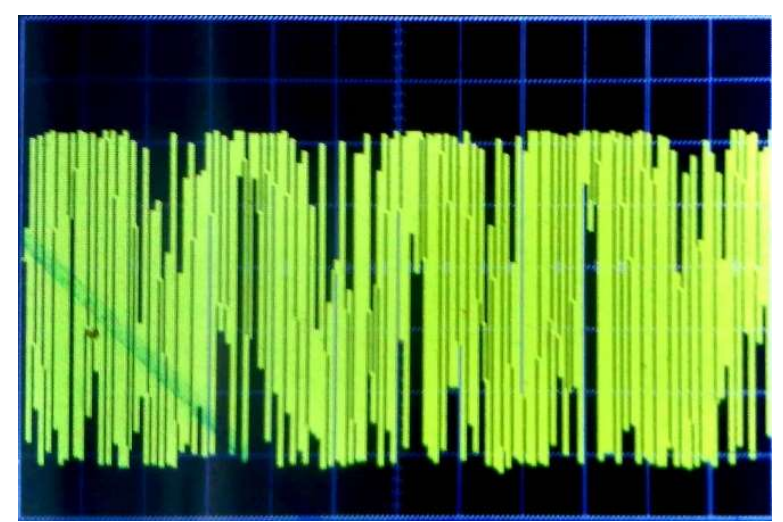

Gambar 9. Sinyal SPWM Pada Modul

Gambar dibawah ini merupakan hasil simulasi dan pengujian menggunakan oscilloscope. Pada pengujian didapatkan THD line-neutral sebesar 1.18 yang akan diredam menggunakan LC filter.

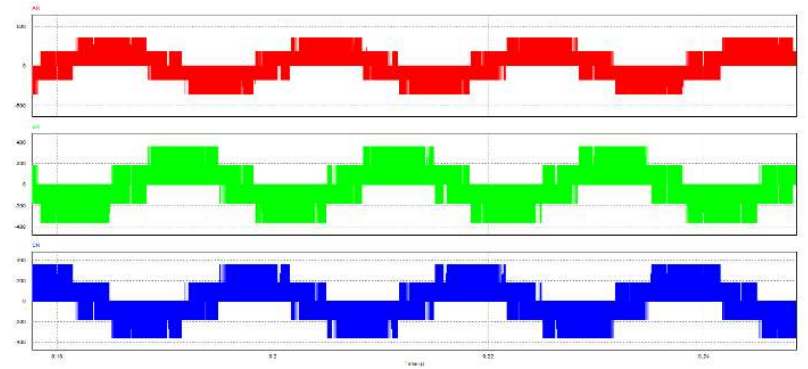

Gambar 10. Hasil Tegangan Line - Neutral Inverter pada Simulasi

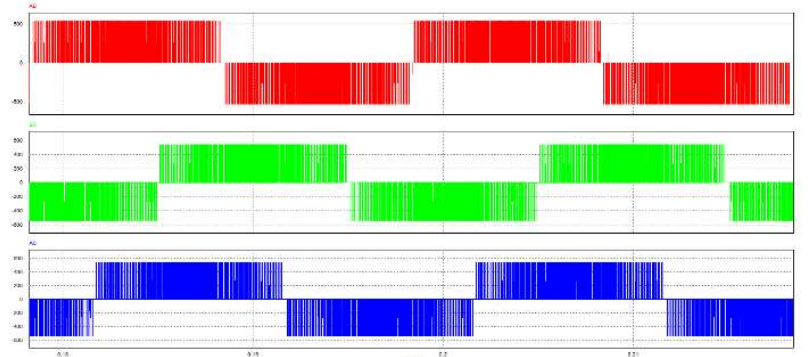

Gambar 11. Hasil Tegangan Line - Line Inverter pada Simulasi

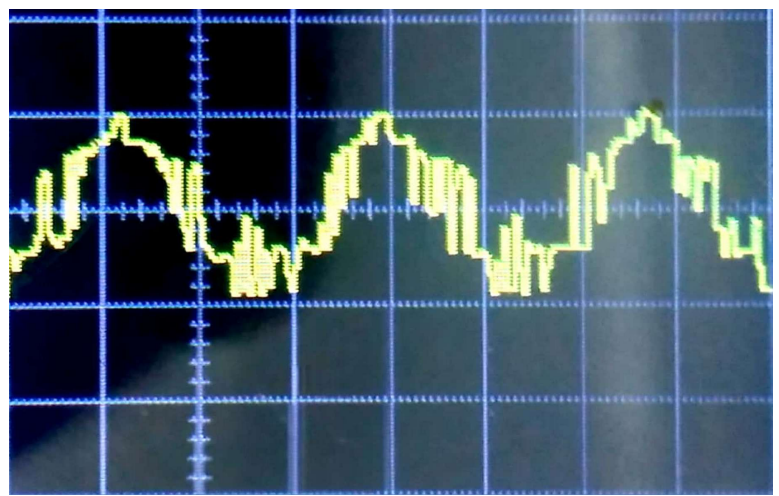

Gambar 12. Hasil Tegangan Line - Neutral Inverter pada Modul 


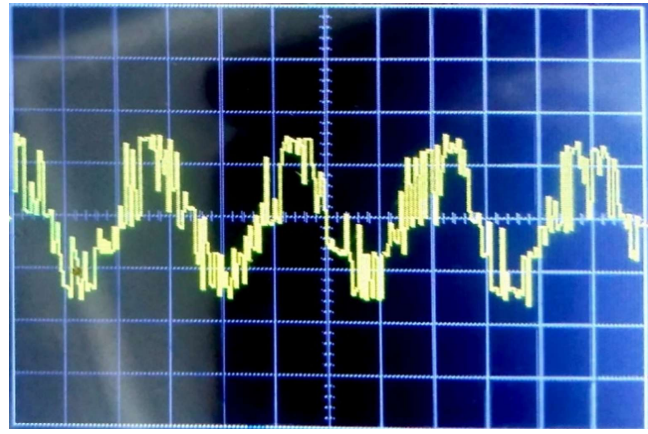

Gambar 13. Hasil Tegangan Line - Line Inverter pada Modul

Tegangan inverter 3 fasa difilter menggunakan induktor 540uH dan kapasitor $16 \mathrm{uF}$. Tegangan output line- neutral $216 \mathrm{~V} \mathrm{AC}$ dan line- line is $378 \mathrm{VAC}$. Setelah harmonisa diredam menggunakan LC filter, hasilnya menjadi 0.03 . Karena harmonisa setelah difilter kurang dari 5 persen, maka output inverter dapat dikoneksikan ke grid. Hasil gelombang sinus setelah difilter seperti pada gambar dibawah ini.

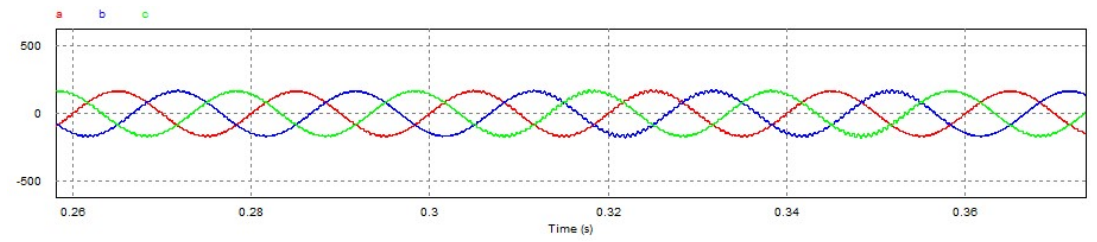

Gambar 14. Hasil Tegangan Line - Neutral Inverter Setelah Difilter pada Simulasi

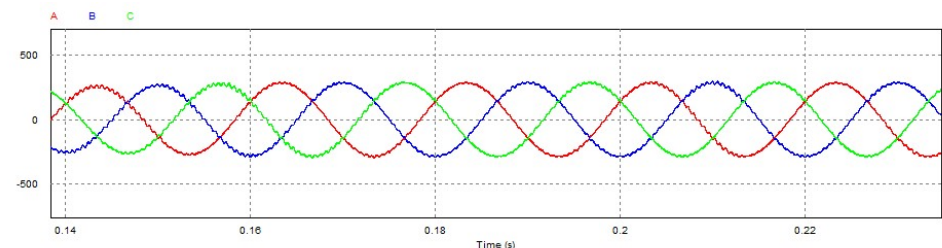

Gambar 15. Hasil Tegangan Line - Line Inverter Setelah Difilter pada Simulasi

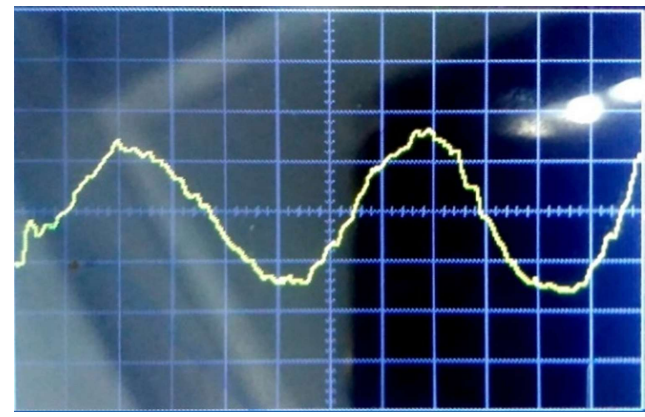

Gambar 16. Hasil Tegangan Line - Neutral Inverter Setelah Difilter pada Modul

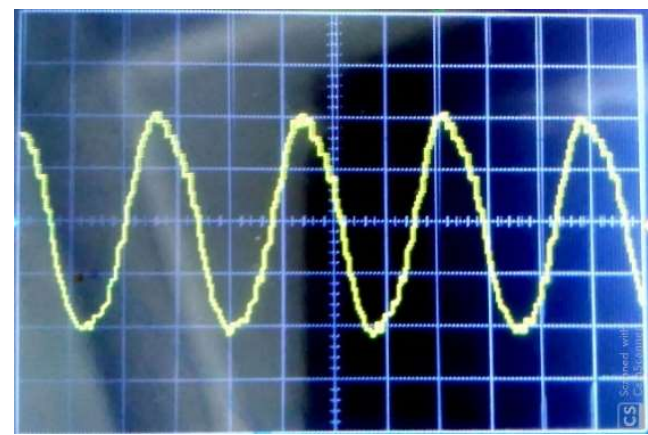

Gambar 16. Hasil Tegangan Line - Line Inverter Setelah Difilter pada Modul 


\section{KESIMPULAN}

Penelitian ini merancang inverter 3 fasa terkoneksi grid pada sistem solar. Hasilnya dapat dibuktikan oleh beberapa hasil dibawah ini:

a. Inverter dapat menghasilkan tegangan output 3 fasa dari 1 sumber tegangan DC yang telah di step up.

b. Metode step up tegangan menggunakan push-pull converter dapat menaikan tegangan dari 60 VDC ke 550 VDC.

c. Sinkronisasi grid pada inverter menggunakan metode SPWM. Karena fasa dan frekuensi pada inverter sesuai dengan grid.

d. Low pass filter digunakan agar tegangan yang dihasilkan menjadi gelombang sinus.

\section{UCAPAN TERIMA KASIH} ini.

Terimakasih kepada politeknik Elektronika Negeri Surabaya yang telah memberikan fasilitas pada penelitian

\section{DAFTAR PUSTAKA}

[1] Yudiarto, Anindhita, Sugiyono, A., Wahid, L. M. A., \& Adiarso. (2018). Outlook Energy Indonesia 2018. Pusat Pengajian Industri Proses Energi.

[2] Taib, S., Sutanto, Y., \& Rahim Abd Razak, A. (2002). Development of simple PWM inverter using photovoltaic cells. In 2002 Student Conference on Research and Development: Globalizing Research and Development in Electrical and Electronics Engineering, SCOReD 2002 - Proceedings. https://doi.org/10.1109/SCORED.2002.1033117.

[3] Yohan Fajar Sidik, F. Danang Wijaya, E. F. (2013). Sinusoidal Pulse Width Modulation Berbasis Lookup Table untuk Inverter Satu Fase Menggunakan 16-Bit Digital Signal Controller. Jnteti.

[4] Errouissi, R., Al-Durra, A., \& Muyeen, S. M. (2016). A Robust Continuous-Time MPC of a DC-DC Boost Converter Interfaced with a Grid-Connected Photovoltaic System. IEEE Journal of Photovoltaics. https://doi.org/10.1109/JPHOTOV.2016.2598271.

[5] Sholihah, F. H., \& Yanaratri, D. S. (2019). Modification of separated DC source for cascade H-bridge multilevel inverter in solar power plant. In AIP Conference Proceedings. https://doi.org/10.1063/1.5095277.

[6] Aliyan,Lalu Riza, Rini Nur Hasanah, M.Aziz Muslim.’Desain Inverter 3 Fasa dengan Minimum Total Harmonic Distortion Menggunakan Metode SPMWM".Juni 2014. 